\title{
Lightning Variability in Dynamically Downscaled Simulations of Alaska's Present and Future Summer Climate
}

\author{
Peter A. Bieniek, ${ }^{a}$ Uma S. Bhatt, ${ }^{\mathrm{b}}$ Alison York, ${ }^{\mathrm{c}}$ John E. WAlsh, ${ }^{\mathrm{a}}$ Rick Lader, ${ }^{\mathrm{a}}$ \\ HEIDI STRADER, ${ }^{\mathrm{d}}$ ROBERT ZIEL, ${ }^{\mathrm{c}}$ RANDI R. JANDT, ${ }^{\mathrm{c}}$ AND RICHARD L. THOMAN ${ }^{\mathrm{a}}$ \\ ${ }^{a}$ International Arctic Research Center, University of Alaska Fairbanks, Fairbanks, Alaska \\ ${ }^{\mathrm{b}}$ Department of Atmospheric Sciences and Geophysical Institute, University of Alaska Fairbanks, Fairbanks, Alaska \\ ${ }^{\mathrm{c}}$ Alaska Fire Science Consortium, University of Alaska Fairbanks, Fairbanks, Alaska \\ ${ }^{\mathrm{d}}$ Alaska Interagency Coordination Center, Fairbanks, Alaska
}

(Manuscript received 29 August 2019, in final form 5 March 2020)

\begin{abstract}
Lightning is a key driver of wildfire activity in Alaska. Quantifying its historical variability and trends has been challenging because of changes in the observational network, but understanding historical and possible future changes in lightning activity is important for fire management planning. Dynamically downscaled reanalysis and global climate model (GCM) data were used to statistically assess lightning data in geographic zones used operationally by fire managers across Alaska. Convective precipitation was found to be a key predictor of weekly lightning activity through multiple regression analysis, along with additional atmospheric stability, moisture, and temperature predictor variables. Model-derived estimates of historical June-July lightning since 1979 showed increasing but lower-magnitude trends than the observed record, derived from the highly heterogeneous lightning sensor network, over the same period throughout interior Alaska. Two downscaled GCM projections estimate a doubling of lightning activity over the same June-July season and geographic region by the end of the twenty-first century. Such a substantial increase in lightning activity may have significant impacts on future wildfire activity in Alaska because of increased opportunities for ignitions, although the final outcome also depends on fire weather conditions and fuels.
\end{abstract}

\section{Introduction}

Wildfire has a prominent role in the boreal forests of Alaska in summer. Although most fires are started by human activity, approximately $90 \%$ of the area burned each year is from wildfires started by lightning (Shulski and Wendler 2007). These lightning-ignited wildfires have been occurring, primarily in interior Alaska, for thousands of years (Lynch et al. 2004). The amount of area burned has increased in recent decades, with an increased frequency of extreme years compared to when formal records first began in the 1940s (Kasischke et al. 2010). The magnitude and extremes of historical Alaska fire seasons have been shown to be linked with broader modes of climate variability (Duffy et al. 2005; Hess et al. 2001; Macias Fauria and Johnson 2006) and anthropogenic climate change (Partain et al. 2016). Future climate projections also anticipate increased wildfire

Corresponding author: Peter A. Bieniek, pbieniek@alaska.edu activity in Alaska over the next century (Melvin et al. 2017; Veraverbeke et al. 2017; Young et al. 2017, 2019). Therefore, understanding the historical drivers, variability, and trends and evaluating possible future changes of lightning activity are important to ultimately tell the story of wildfires in Alaska.

Lightning activity has been a concern in the Alaska fire weather research community since at least the 1950s. The first study of lightning activity in Alaska was conducted by Sullivan (1963) who estimated thunderstorm development using surface weather charts and found that surface convergence and stability were key to their development. This study was later followed by analysis of lightning/ thunderstorm activity through satellite retrievals (Biswas and Jayaweera 1976) and records maintained by the Bureau of Land Management (Grice and Comiskey 1976) that established the first lightning climatologies for Alaska. The network of lightning sensors currently used to monitor lightning activity in Alaska underwent initial testing in the late 1970s (Krider et al. 1980). 
Since its initial deployment, the detection sensors have been upgraded several times. These changes have led to changes in both the coverage and accuracy/efficiency of the network (Dissing and Verbyla 2003; Farukh and Hayasaka 2012; Farukh et al. 2011a; Fronterhouse 2012), resulting in a heterogeneous record in both space and time.

Climatologies developed through various historical studies of observed lightning activity show that most thunderstorms occur in interior Alaska in June-July (Biswas and Jayaweera 1976; Grice and Comiskey 1976; Reap 1991). The thunderstorms that generate this lightning activity are generally driven by either the air mass or synoptic forcing in Alaska (Biswas and Jayaweera 1976). As is the general case with thunderstorms, instability is a key driver and has been shown to be a potential proxy for lightning activity in Alaska (Farukh et al. 2011a; Reap 1991; Sullivan 1963). Thunderstorm activity has also been shown to be enhanced due to land surface characteristics such as vegetation and topography (Dissing and Verbyla 2003). In addition, burn scars from earlier wildfires may increase the potential for thunderstorm development (Mölders and Kramm 2007).

The recent large fire years of 2004, 2005, and 2015 have all been attributed to lightning ignitions (Farukh et al. 2011b; Partain et al. 2016; Wendler et al. 2011). Efforts to better predict lightning and lightning-caused fires have been ongoing and have ranged from statistical approaches (Duffy et al. 2005; Farukh et al. 2011a; Reap 1991) to atmospheric circulation map-type analysis (Henry 1978). Given the recent increases in wildfire activity (Kasischke et al. 2010) and projections for continued increases (Melvin et al. 2017), understanding how lightning activity has changed or might change in the future is needed to better plan for future fire seasons. Globally, lightning activity is anticipated to increase as the climate warms over the next century according to model projections (Krause et al. 2014; Price and Rind 1994). Lightning and lightning-caused fires are also projected to increase in the contiguous United States (Romps et al. 2014) and in Alaska over the same period (Veraverbeke et al. 2017).

While the studies highlighted above provide general indications of wildfire trends, there is a need for more quantitative assessments of historical and future projections of lightning activity across Alaska. This paper studies lightning on weekly to seasonal scales over specific geographic regions (i.e., Predictive Service Areas) used operationally by fire managers to provide information that can support long-term decision making. Novel aspects of this study also include the use of dynamically downscaled climate data to evaluate lightning in Alaska and an assessment of historical trends.

\section{Data and methods}

Dynamically downscaled reanalysis and global climate model (GCM) simulations of future climate were used to analyze historical and projected lightning activity in Alaska. The ERA-Interim reanalysis (Dee et al. 2011) was downscaled for the period 1979-2015 to provide the historical observations. The historical and RCP8.5 emission scenario simulations from two GCMs of phase 5 of the Coupled Model Intercomparison Project (CMIP5) were downscaled for 1970-2100. The two GCMs were the Geophysical Fluid Dynamics Laboratory Coupled Physical Model, version 3 (GFDL), and National Center for Atmospheric Research Community Climate System Model, version 4 (CCSM). The ERA-Interim reanalysis was selected because it was one of the best-performing products over the Alaska and Arctic domains (Lader et al. 2016; Lindsay et al. 2014). Walsh et al. (2018) show that CCSM and GFDL ranked first and third, respectively, among 21 CMIP5 GCMs in the simulation of the seasonal cycles of temperature, precipitation, and sea level pressure over Alaska. RCP8.5 is the highest forcing scenario with the greatest degree of warming in Alaska over lower scenarios such as RCP4.5 (Markon et al. 2018), and it was selected because observed carbon dioxide emissions have continued to best track RCP8.5 (Peters et al. 2013).

The reanalysis and GCM projection data were dynamically downscaled using the Advanced Research version of the Weather Research and Forecasting (WRF) Model (ARW; Skamarock et al. 2008) over the entire Alaska domain [see Fig. 1a in Bieniek et al. (2016)]. The model provided 20-km spatial resolution data that better account for the complex topography of Alaska than the relatively coarse $(100-200 \mathrm{~km})$ reanalysis or GCM data, and the output was saved at hourly time increments (Bieniek et al. 2016). Although $20-\mathrm{km}$ spatial resolution is still generally too coarse to evaluate individual thunderstorms, it provides detailed meteorological data that can be used to evaluate the general atmospheric characteristics associated with weekly to seasonal lightning activity over broader regions as in our study. The WRF Model was reinitialized at 48-h intervals with an additional 6-h spinup time and a spectral nudging procedure that constrained the downscaled fields to be consistent with the driving reanalysis or GCM. Clouds and precipitation in the WRF Model were parameterized by the Morrison 2-moment (Morrison et al. 2009) and Grell 3D cumulus schemes. Shortwave and longwave radiative effects were 


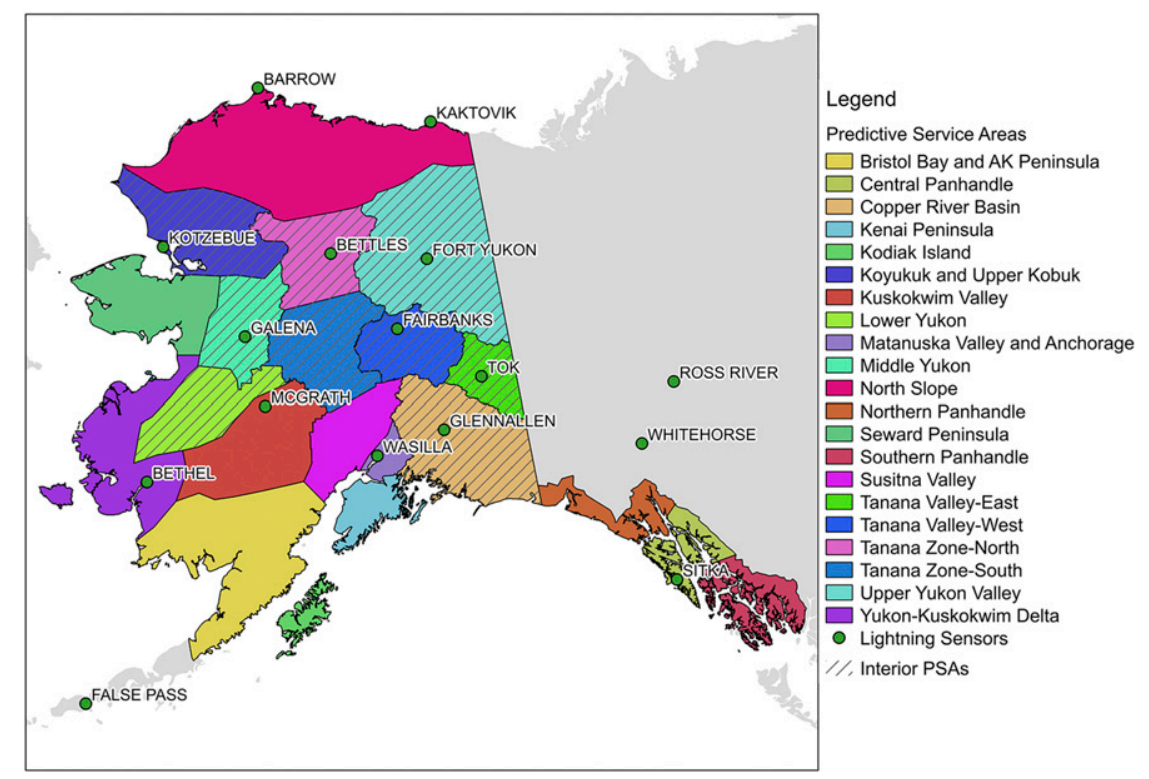

FIG. 1. Map of Alaska PSAs and locations of the lightning sensors (points) as of 2017. Interior PSAs have gray hatching.

parameterized by the Rapid Radiative Transfer Model for GCMs (Iacono et al. 2008). Boundary layer and surface layer processes utilized the Mellor-YamadaJanjić (Janjić 1994) and Janjić eta (Monin-Obukhov) schemes, respectively. A thermodynamic sea ice model (Zhang and Zhang 2001) was coupled with the Noah land surface model used within WRF to better model the thermal conditions over sea ice. The WRF Model configuration, physics, and temperature and precipitation output are described and evaluated in detail in Bieniek et al. (2016).

Observed cloud-to-ground lightning strike data were obtained from the Alaska Lightning Detection Network (ALDN) for 1986-2015 (1987 and 1989 were not included in our analysis due to missing data). The ALDN data consist of the location, date, and time of each lightning strike determined by a network of magneticdirection-finding stations (see locations of the stations as of 2017 in Fig. 1). To best work with these data, the number of lightning strikes over land were counted within each $20-\mathrm{km}$ grid box each day on the same grid as the dynamically downscaled meteorological data described above. The count of strikes was produced at a daily scale and then summed over each week for the evaluation. This procedure ultimately resulted in weekly 20-km grids of observed lightning strike counts covering all of Alaska over 1986-2015 but they required additional homogenization prior to conducting our analysis.

The network of ALDN lightning sensors used to produce the weekly observed lightning strike count grids was first developed in the 1970s (Krider et al. 1980) and has been upgraded and expanded multiple times since (Farukh and Hayasaka 2012; Fronterhouse 2012). These upgrades have changed the detection accuracy and efficiency, especially after 2000 when sensors were upgraded to Vaisala Impact ES sensors and detection efficiency increased from $40 \%-80 \%$ to $80 \%-90 \%$ (Farukh and Hayasaka 2012; Farukh et al. 2011a). The network was further upgraded to a completely new set of time-of-arrival sensors (operated by TOA Systems, Inc.) after 2012. These changes in detection efficiency and accuracy through the record make the data challenging to use for assessing the variability and trends of lightning over the historical period. One key difference from the original network was that the post-2012 sensors counted the individual strokes per flash rather than only the flashes of lightning. That switch resulted in a change in the character of the data after 2012. To correct for this specific issue, the lightning data were homogenized by exploiting the strike multiplicity information that was included in the pre-2012 data, which provides an estimate of the number of strokes that occurred within each flash of lightning. The multiplicity parameter (i.e., the number of strokes) was summed for the pre-2012 data instead of counting each flash that occurred in each $20-\mathrm{km}$ grid box. This simple approach provides an estimated number of lightning strokes each year over the 1986-2011 period that is more in line with how lightning was observed during the $2012-15$ period in the interior (Fig. 2). On average this procedure increased the lightning counts in 1979-2011 by approximately 1.5 times. The final gridded observed lightning product representing 


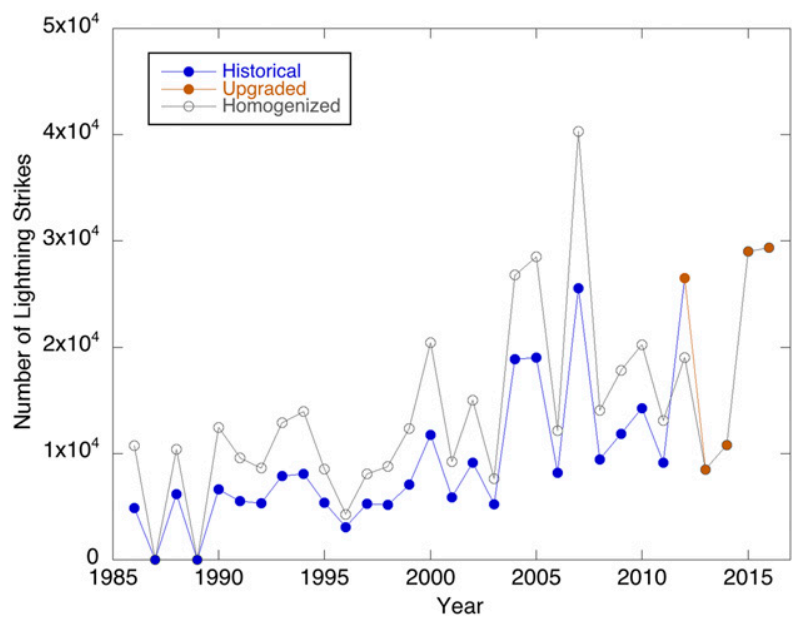

FIG. 2. May-August counts of lightning strikes across the interior PSAs for the historical network (1986-2012; blue), the new upgraded sensor network (2012-15; orange), and the historical homogenized strike counts (gray). The homogenized data are used in this study and are referred to as the observed data unless otherwise noted.

the number of lightning strokes across all of Alaska for 1986-2015 will be analyzed in this study. Hereinafter, these gridded homogenized lightning data will be referred to as the observations unless otherwise noted. In addition, we will hereinafter refer to lightning strikes rather than strokes for simplicity. It is important to note that, while we took steps to homogenize the observed lightning data, many heterogeneities still exist that require considerable caution when interpreting variability and change using these data. These heterogeneities specifically include changes in sensor coverage especially in regions outside of interior Alaska where lightning may not have been observed earlier in the historical record. Similar issues had to be addressed in the lightning climatology studies performed for the contiguous United States by Koshak et al. (2015) with regard to various upgrades in the National Lightning Detection Network.

The analysis in this study was conducted statewide and aggregated over 21 Predictive Service Areas (PSAs; see map in Fig. 1). These PSAs are used by fire managers and weather forecasters at the Alaska Interagency Coordination Center and the Alaska Fire Service to operationally assess fire risk. The $20-\mathrm{km}$ downscaled weather/climate parameters and observed lightning data were masked and aggregated to the PSAs. Conducting our analysis following the PSAs makes the results from the study more readily useable to the Alaska fire management community. The large geographic extent of the PSA does not allow for the evaluation of lightning at the scale of individual thunderstorms, which was not the focus of this study. Instead, the focus of this study is on the broader weekly to monthly variability of lightning activity for which a coarser spatial scale is warranted. We focused our analysis on the interior Alaska subset of the PSAs (hereinafter referred to as the interior PSAs): Tanana Valley-West, Tanana Zone-South, Koyukuk and Upper Kobuk, Lower Yukon, Upper Yukon Valley, Copper River Basin, Tanana Zone-North, and Tanana Valley-East. The interior PSAs were selected as a focus of our study because they have had the most consistent lightning observations through time, encompass most of Alaska's historical burned areas (Shulski and Wendler 2007), and are primarily located within the interior climate divisions (Bieniek et al. 2012). Results for the other PSAs will be shown for reference when applicable but they contain higher uncertainty because of the more limited and heterogenous records of lightning observations available in those regions.

The observed lightning and reanalysis data were related and explored in the context of multiple linear regression analysis at a weekly time scale within each PSA. The weekly time scale was selected to capture the shorter duration of synoptic events that lead to subseasonal to seasonal variability of lighting activity without attempting to capture the more local and shorter time scale meteorological conditions that drive individual thunderstorms. The weekly aggregated lightning data and the five reanalysis predictor variables (discussed below) were fit over 1999-2014 using the weeks in June-July by least squares regression. This training period was selected because most of the years had relatively stable sensor coverage and excluded the years of 1986-98 and 2015 for evaluation purposes. The 1999-2014 period also incorporates the years in 1999-2011 that were homogenized as described earlier in this section, therefore some uncertainty was likely added to the fitting data. However, it was necessary to have enough years of data to best represent the atmospheric conditions that lead to lightning activity in Alaska, so those years were included. It is also very challenging to accurately compare the results of the regression models with the 1986-98 observations for many PSAs since sensor coverage was sparse, especially earlier in the record. The atmospheric predictor variables considered were convective precipitation amount, 2-m temperature, dewpoint temperature, 500-hPa height, and the $850-500-\mathrm{hPa}$ temperature difference. These predictor variables were considered as they have all been evaluated in prior studies of Alaska lightning activity (e.g., Reap 1991; Peterson et al. 2010). We focused our regression analysis on the June-July period since that is the core period of Alaska lightning activity, therefore the use of the regression models beyond these months should only be done with caution. 

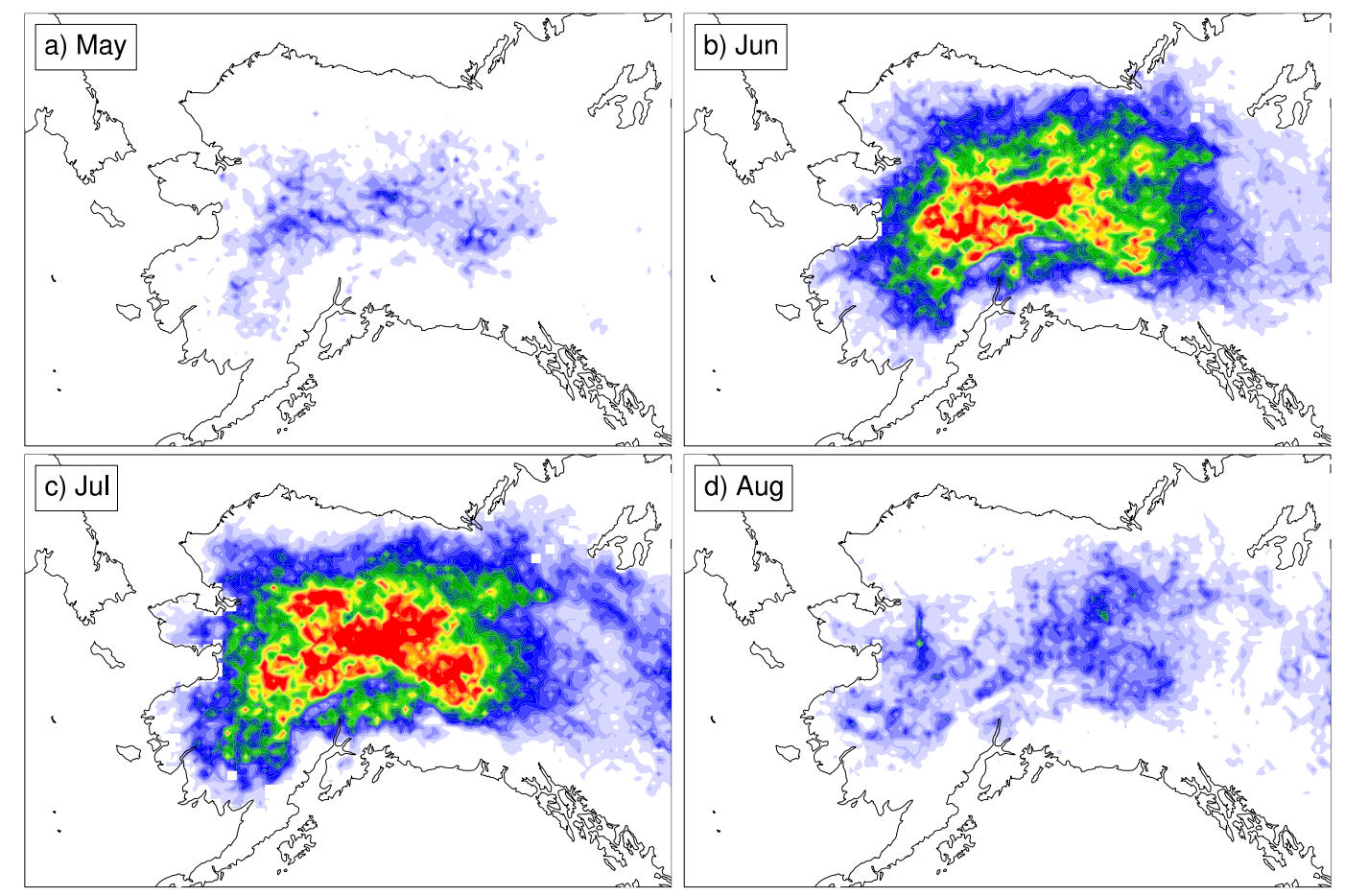

$\begin{array}{llllllllllllll}2 & 4 & 6 & 8 & 10 & 12 & 14 & 16 & 18 & 20 & 22 & 24 & 26\end{array}$

FIG. 3. Monthly average number of lightning strikes in each 20-km grid box over 1986-2015 for (a) May, (b) June, (c) July, and (d) August.

The best-fit regression model for each PSA was determined by the stepwise Akaike information criteria (AIC) approach (Wilks 2006). The regressions were analyzed using Pearson's correlation and also dominance analysis (Budescu 1993) to determine the relative contribution of each predictor variable in the variability of the model-estimated lightning activity. Trends were evaluated through the Theil-Sen trend estimator approach, and the percent change was determined using the applicable endpoint values of the regression line. The statistical significance of the correlations was assessed using a two-tailed Student's $t$ test at the 95\% level. The significance of the trends was evaluated by the Mann-Kendall trend test.

\section{Results and discussion}

\section{a. Historical lightning climatology}

The gridded monthly averaged observed lightning over 1986-2015 is shown for May, June, July, and August in Fig. 3. Most lightning activity occurs in June and July, with some $20-\mathrm{km}$ grid cells in the interior of Alaska receiving more than 30 strikes per month on average. Climatologically, very little lightning occurs along the coasts and on the North Slope even during the peak months. These findings are spatially consistent with the earlier lightning climatologies developed for Alaska (Biswas and Jayaweera 1976; Grice and Comiskey 1976; Reap 1991). In contrast to June and July, very little lightning activity occurs in May and August. What little lightning occurs in these months is also mostly in the interior.

The total number of strikes each May-August season was summed over the interior PSAs and is shown in Fig. 4. The average number of lightning strikes in the interior over the summer is 13786 with a standard deviation of 8662 . The four years that exceeded 1 standard deviation above the mean lightning strikes occurred after 2000 and were 2004, 2005, 2015, and 2007. The Alaska fire seasons of 2004, 2005, and 2015 are three of the four the largest seasons as measured by the total area burned on record, and lightning was cited as a key driver for their large magnitudes (Farukh et al. 2011b; Partain et al. 2016; Wendler et al. 2011). The 2007 season had below-average area burned due to relatively wet fuels from rainfall that limited fire growth even though there were many lightning-caused fires.

Lightning is a result of thunderstorms and convection. The dynamically downscaled convective precipitation 


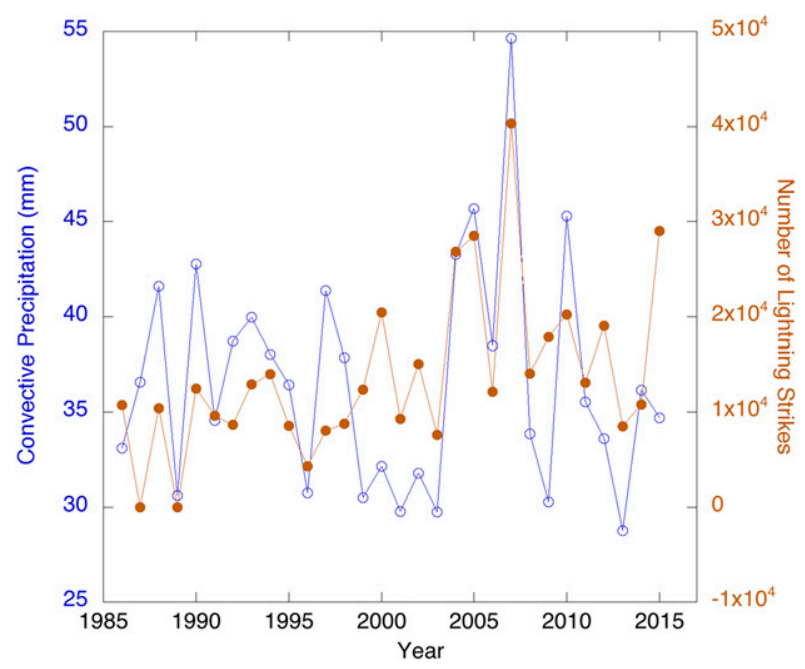

FIG. 4. May-August interior PSA average convective precipitation from the downscaled ERA-Interim reanalysis (blue) and observed number of lightning strikes (orange).

variable output from the WRF cumulus parameterization scheme was considered as a potential simple estimate of thunderstorm activity. When the downscaled reanalysis convective precipitation was compared with the lightning observations summed over the interior, there was an overall correlation of 0.53 (Fig. 4). This correlation indicates that seasons with higher lightning activity occur in conjunction with enhanced convective precipitation and this is especially apparent for the peak lightning years after 2000. The correspondence of lightning and convective precipitation also extends climatologically over the entire May-August season. The 1979-2015 monthly average downscaled ERA-Interim convective precipitation is shown in Fig. 5. Like the lightning climatologies shown in Fig. 3, the largest amounts of convective precipitation occur on average in June and July with lesser amounts in May and August. The core months and region of lightning activity in interior Alaska align well with the climatological convective precipitation based on this analysis.

Precipitation from WRF has been used to broadly evaluate observed lightning activity in other regions (Giannaros et al. 2015; Yair et al. 2010) and in GCMs (Magi 2015). Typically, there is higher lightning activity with higher convective precipitation amounts in observations (Gungle and Krider 2006). The results of these prior studies, while not conducted in Alaska, are consistent with our findings. However, one additional caveat for Alaska is that lightning also occurs in dry thunderstorms in which precipitation does not reach the
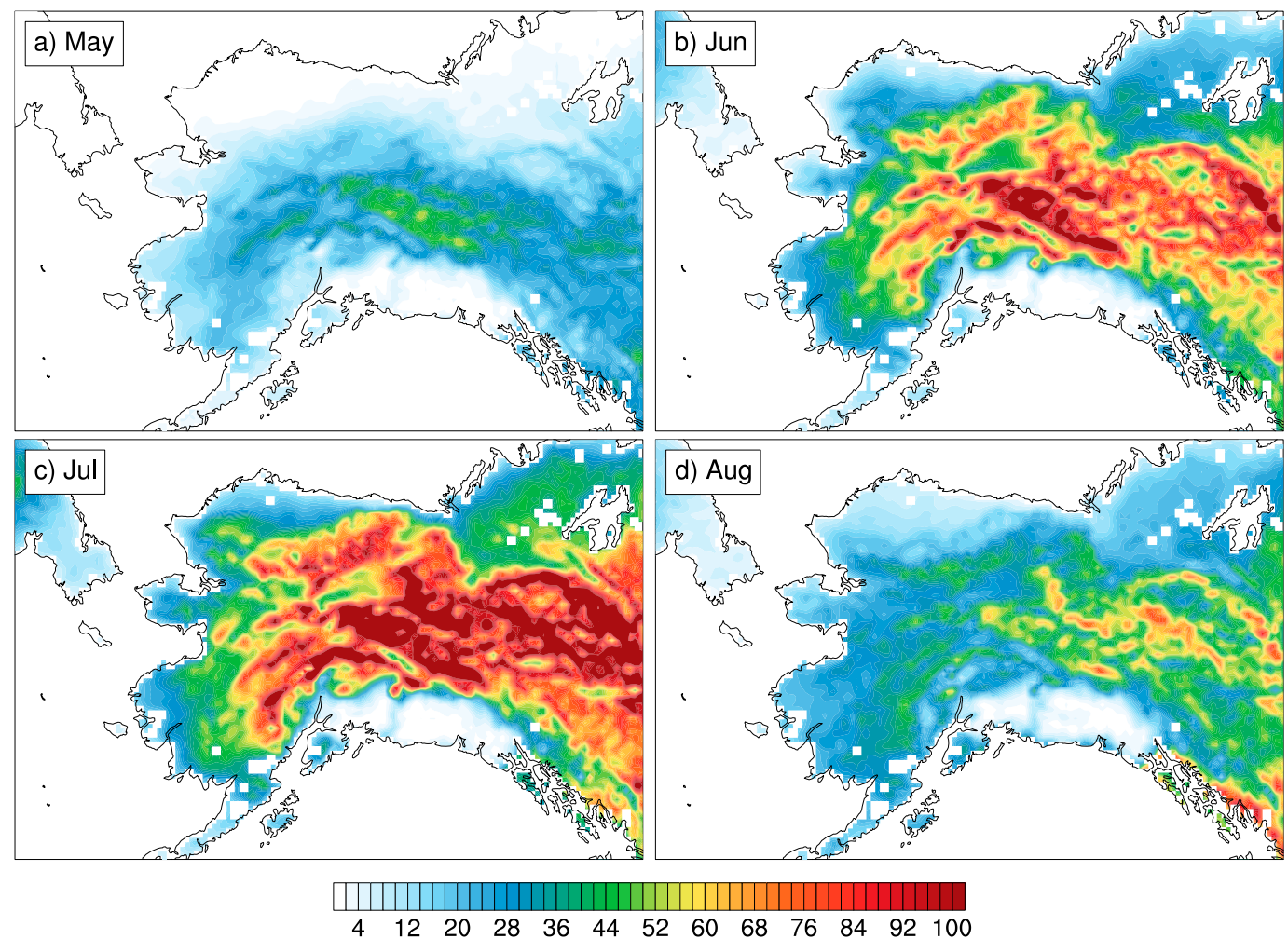

FIG. 5. Monthly average amount of the downscaled ERA-Interim reanalysis convective precipitation (mm) over 1979-2015 for (a) May, (b) June, (c) July, and (d) August. 
TABLE 1. Multiple regression coefficients for estimating weekly lightning strike numbers in each PSA. Coefficients are shown for convective precipitation (CP), 850-500-hPa temperature difference (dT), 2-m dewpoint temperature (Td), 2-m temperature (T2m), and $500-\mathrm{hPa}$ heights $(500 \mathrm{hPa})$. Blank cells indicate predictor variables that were not included in the regression equation for each PSA after stepwise AIC model reduction.

\begin{tabular}{|c|c|c|c|c|c|c|}
\hline PSA & Intercept & $\mathrm{CP}$ & $\mathrm{dT}$ & $\mathrm{Td}$ & $\mathrm{T} 2 \mathrm{~m}$ & $500 \mathrm{hPa}$ \\
\hline Northern Panhandle & 4.0 & & & 14.5 & & \\
\hline Central Panhandle & 1.2 & & 3.2 & 5.3 & -5.1 & 4.2 \\
\hline Southern Panhandle & 1.4 & & 1.7 & & & 0.9 \\
\hline Matanuska Valley and Anchorage & 29.4 & & 23.3 & 24.9 & & -16.8 \\
\hline Kenai Peninsula & 10.9 & & & 13.8 & 17.4 & -23.7 \\
\hline Tanana Valley-West & 924.4 & 431.7 & 187.6 & 396.5 & & \\
\hline Susitna Valley & 253.6 & & 116.6 & 260.5 & & -126.3 \\
\hline Tanana Zone-South & 1438.6 & 1278.3 & & & & 456.8 \\
\hline Koyukuk and Upper Kobuk & 289.9 & 124.8 & 156.2 & 226.9 & & -114.1 \\
\hline Lower Yukon & 546.5 & 564.1 & 139.3 & -175.3 & & 241.6 \\
\hline Middle Yukon & 651.5 & 435.5 & 267.6 & & & 101.5 \\
\hline Upper Yukon Valley & 2055.3 & 1192.3 & 289.2 & & & 504.5 \\
\hline Copper River Basin & 301.1 & & 146.4 & 363.0 & -178.1 & \\
\hline Kodiak Island & 0.3 & & & & & \\
\hline North Slope & 361.3 & 228.4 & 318.1 & 232.4 & -237.0 & \\
\hline Tanana Zone-North & 842.3 & 338.5 & 273.8 & 354.5 & & \\
\hline Seward Peninsula & 230.1 & 316.2 & 76.7 & -98.2 & & 68.2 \\
\hline Bristol Bay and Alaska Peninsula & 221.2 & 211.9 & 97.5 & & & 110.7 \\
\hline Yukon-Kuskokwim Delta & 199.0 & 149.3 & 79.5 & & & \\
\hline Tanana Valley-East & 397.2 & 180.4 & & 223.8 & & -84.6 \\
\hline Kuskokwim Valley & 826.7 & 590.2 & 246.1 & & & 201.2 \\
\hline
\end{tabular}

ground and can lead to greater likelihoods that wildfires will be ignited (Peterson et al. 2010). Dry thunderstorms would not be accurately reflected under the hypothesis that more convective precipitation leads to more lightning. As a result, convective precipitation only explains a portion of the variability of lightning at the monthly to seasonal scale.

To create a more complete picture of the local climate-scale drivers of lightning, additional predictor variables were compared with lightning at the weekly scale using multiple linear-regression analysis. These predictors include stability, humidity and temperature variables, described below and in section 2 (data and methods), that help to better account for conditions where lightning may occur but convective precipitation amounts are low. These variables were selected as they are associated with known "rules of thumb" in the Alaska weather forecasting community and are generally consistent with similar studies evaluating the meteorological drivers of Alaska lightning (i.e., Calef et al. 2008; Farukh et al. 2011a; Peterson et al. 2010; Reap 1991; Veraverbeke et al. 2017). The analysis was constrained to the PSA level for best consistency with Alaska fire manager needs while accounting for regional variations in lightning-climate links across the state. The downscaled reanalysis parameters specifically considered as predictor variables were convective precipitation, the 850-500-hPa temperature difference (dT), 2-m dewpoint temperature, 2-m temperature, and 500-hPa height. The variables were first normalized by subtracting the mean and dividing by the standard deviation and then analyzed using multiple regressions to find the optimal models for each PSA. The normalized variables were then used as predictors to reduce the impacts of the biases in the downscaled ERA-Interim reanalysis (Bieniek et al. 2016). The final results for each PSA and the values of the coefficients of the regression equation are given (when applicable) in Table 1. When the regression estimates of lightning were compared with the observations over June-July (Fig. 6) all PSAs had correlations greater than 0.30 while many in the interior exceeded 0.5 .

The amount of weekly observed lightning variance explained by the regression model estimates and the contribution of individual predictors are shown in Table 2. Convective precipitation accounted for most of the variance explained for most PSAs, especially those located in the interior. Multiple prior studies have similarly evaluated lightning and/or lightning-ignited fires in Alaska by regression analysis (Calef et al. 2008; Farukh et al. 2011a; Reap 1991; Veraverbeke et al. 2017). As in our analysis, most prior studies considered stability predictor variables such as convective available potential energy (CAPE) or the 850-500-hPa lapse rate (as in our study) and additional variables such as wet-bulb temperature (e.g., Koshak et al. 2015; Jayaratne and Kuleshov 2006; Williams and Renno 1993), surface 


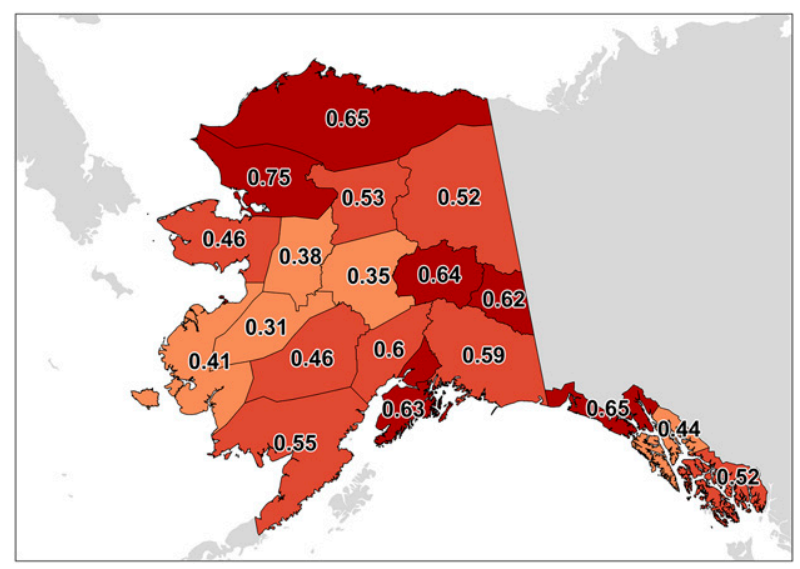

FIG. 6. Correlations $R$ of June-July regression estimates of lightning strike counts vs observations for 1986-2015 for each PSA. Darker red shading corresponds to higher correlation values. All correlations were significant at the $95 \%$ or greater level except for the Tanana Zone-South and Lower Yukon PSAs.

temperature, and dewpoint. However, all studies had an eye to different spatial and time scales. While our analysis looked at weekly/PSA estimates of lightning, our results and the final predictor variables were broadly consistent with the prior lightning-regression studies in Alaska.

Since convective precipitation is a key driver in the regression models for most PSAs the question of lightning that occurs in thunderstorms with little or no precipitation is of concern since some lightning activity could be missed even when considering the additional nonprecipitation predictor variables. In this analysis we focus on weekly-to-seasonal-scale lightning variability; therefore, an analysis of precipitation for individual strikes and thunderstorms is beyond the scope of this study. However, analysis of weekly precipitation and lightning data will highlight if lightning also occurred during dry conditions in each PSA. Figure 7 shows a comparison of the ranges of all of the interior PSA JuneJuly weekly averaged convective precipitation amounts when one or more strikes occurred in the corresponding PSA during the week for 1999-2015. Likewise, the amounts of convective precipitation were also binned for weeks in the same PSAs where no lightning was observed are shown for comparison (Fig. 7). Weeks with observed lightning activity (Fig. 7a) covered a broad range of convective precipitation amounts in the interior, and the results also show that many weeks have lightning even within the lowest $0-1 \mathrm{~mm} \mathrm{day}^{-1} \mathrm{bin}$. The modeled estimates based on our predictors (Fig. 7b) shows very similar results, although the model has about $15 \%$ fewer PSA-week lightning events than the observations in the lowest $0-1 \mathrm{~mm} \mathrm{day}^{-1}$ range. Therefore, the PSA regression models reasonably capture lightning activity even during weeks with relatively low precipitation amounts.

TABLE 2. Coefficient of determination $R^{2}$ for each PSA determined by dominance analysis and the total value for the weekly fitting period of 1999-2014. Values are shown for convective precipitation (CP), 850-500-hPa temperature difference (dT), 2-m dewpoint temperature $(\mathrm{Td}), 2-\mathrm{m}$ temperature $(\mathrm{T} 2 \mathrm{~m})$, and $500-\mathrm{hPa}$ heights $(500 \mathrm{hPa})$. Cells are blank if the predictor variable was not part of the regression equation for the PSA.

\begin{tabular}{|c|c|c|c|c|c|c|}
\hline PSA & $\mathrm{CP}$ & $\mathrm{dT}$ & $\mathrm{Td}$ & $\mathrm{T} 2 \mathrm{~m}$ & $500 \mathrm{hPa}$ & Total fitted \\
\hline Northern Panhandle & & & 0.10 & & & 0.10 \\
\hline Central Panhandle & & 0.02 & 0.04 & 0.02 & 0.03 & 0.11 \\
\hline Southern Panhandle & & 0.09 & & & 0.03 & 0.12 \\
\hline Matanuska Valley and Anchorage & & 0.15 & 0.08 & & 0.02 & 0.25 \\
\hline Kenai Peninsula & & & 0.08 & 0.07 & 0.09 & 0.25 \\
\hline Tanana Valley-West & 0.05 & 0.14 & 0.14 & & & 0.33 \\
\hline Susitna Valley & & 0.09 & 0.15 & & 0.03 & 0.27 \\
\hline Tanana Zone-South & 0.37 & & & & 0.03 & 0.40 \\
\hline Koyukuk and Upper Kobuk & 0.11 & 0.10 & 0.10 & & 0.02 & 0.32 \\
\hline Lower Yukon & 0.19 & 0.09 & 0.05 & & 0.02 & 0.34 \\
\hline Middle Yukon & 0.20 & 0.14 & & & 0.01 & 0.34 \\
\hline Upper Yukon Valley & 0.24 & 0.06 & & & 0.04 & 0.33 \\
\hline Copper River Basin & & 0.03 & 0.09 & 0.03 & & 0.16 \\
\hline \multicolumn{7}{|l|}{ Kodiak Island } \\
\hline North Slope & 0.11 & 0.13 & 0.07 & 0.04 & & 0.36 \\
\hline Tanana Zone-North & 0.07 & 0.05 & 0.07 & & & 0.19 \\
\hline Seward Peninsula & 0.22 & 0.09 & 0.05 & & 0.01 & 0.36 \\
\hline Bristol Bay and Alaska Peninsula & 0.12 & 0.09 & & & 0.02 & 0.23 \\
\hline Yukon-Kuskokwim Delta & 0.14 & 0.08 & & & & 0.22 \\
\hline Tanana Valley-East & 0.17 & & 0.14 & & 0.02 & 0.33 \\
\hline Kuskokwim Valley & 0.18 & 0.10 & & & 0.01 & 0.30 \\
\hline
\end{tabular}



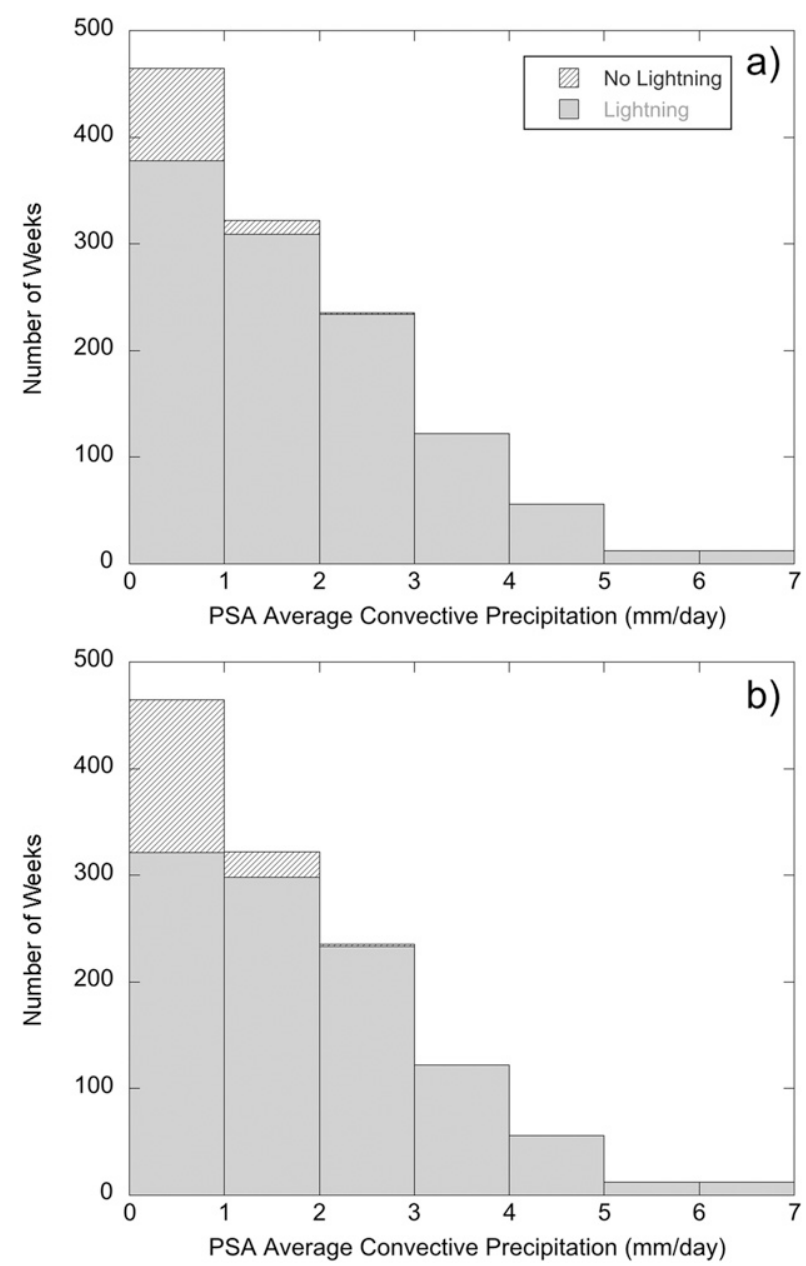

FIG. 7. June-July counts of weekly average convective precipitation amounts when one or more lightning strikes were (a) observed and (b) estimated by the regression models over any interior PSA for 1999-2015. Solid gray bars indicate the counts for cases when at least one or more lightning strikes were present in a PSA, and hatched bars indicate counts of weeks when no strikes were present.

\section{b. Past and anticipated variability and trends}

Evaluating the variability and trends of the historical lightning data has been challenging due to the heterogeneities that arise from the upgrades made to the network since its inception (Farukh and Hayasaka 2012; Farukh et al. 2011a). Therefore, it is informative to compare the observed lightning trends with the model estimates output by the regressions over the historical period. The percent change of the observed and regression-estimated lightning from the downscaled ERA-Interim reanalysis are shown for each PSA for June-July in Figs. 8a and 8b. The observed lightning over 1986-2015 (Fig. 8a) increased by more than 100\% in most PSAs with a few, notably the North Slope and
Koyukuk and Upper Kobuk, above $10000 \%$ and 500\%, respectively. The downscaled reanalysis estimates of lightning over 1979-2015 were much more subdued with increases ranging from $-4 \%$ to $62 \%$ in the interior PSAs (Fig. 8b). The trends were even lower in the reanalysis estimates when considered over the 1986-2015 period (not shown). Averaged over all of the interior PSAs, the June-July observed lightning increased by $98 \%$ while the reanalysis estimated an increase of 17\% (Fig. 9a), however only the observed trend was significant at the $90 \%$ level. The trend of the observed lightning was therefore approximately one order of magnitude greater than the regression-estimated lightning from the reanalysis over a similar time period. Only one PSA, Tanana Valley-West, had similar trends in both the observations and the reanalysis estimates ( $\sim 10 \%$ change). Fairbanks is located in this PSA and has been the focus of the lightning detection network since its initial deployment and may have a more physically realistic trend through time than the other PSAs where additional lightning sensors have been added later and therefore have steeper and likely spurious trends.

Given the large differences between the trends in the observed and the modeled estimates of historical lightning, a closer look into the historical June-July lightning for the observed (corrected and uncorrected) and model estimates are shown for the Tanana ValleyWest and Yukon-Kuskokwim Delta PSAs (Fig. 10). These two PSAs provide contrasting views since the Tanana Valley-West PSA (Fig. 10a) contains Fairbanks and has the longest history of lightning sensor coverage while the Yukon-Kuskokwim Delta PSA (Fig. 10b) has always had limited sensor coverage. The corrected and uncorrected observations of lightning and modeled estimates based on the downscaled reanalysis for the Tanana Valley-West PSA both experienced a similar order of magnitude of change, $9.8 \%$ and $7.4 \%$, respectively, over 1986-2015, while the uncorrected lightning experienced a more significant change of $73.3 \%$ due to the change in the accounting of lightning strokes/flashes later in the record. In contrast, the coastal YukonKuskokwim Delta PSA experienced changes of 536.2\% and $178.5 \%$ in the uncorrected and corrected observations, respectively, while the modeled estimates showed a relatively slight decline of $-6.9 \%$. Here, the uncertainty of the strike data is much larger since sensor coverage has been limited through time. Therefore, regions like the Yukon-Kuskokwim Delta PSA show a much greater sensitivity in the variability of lightning strike counts due to changes in the network than those in the interior where lightning sensors have been in operation throughout the record and should be viewed with caution. 

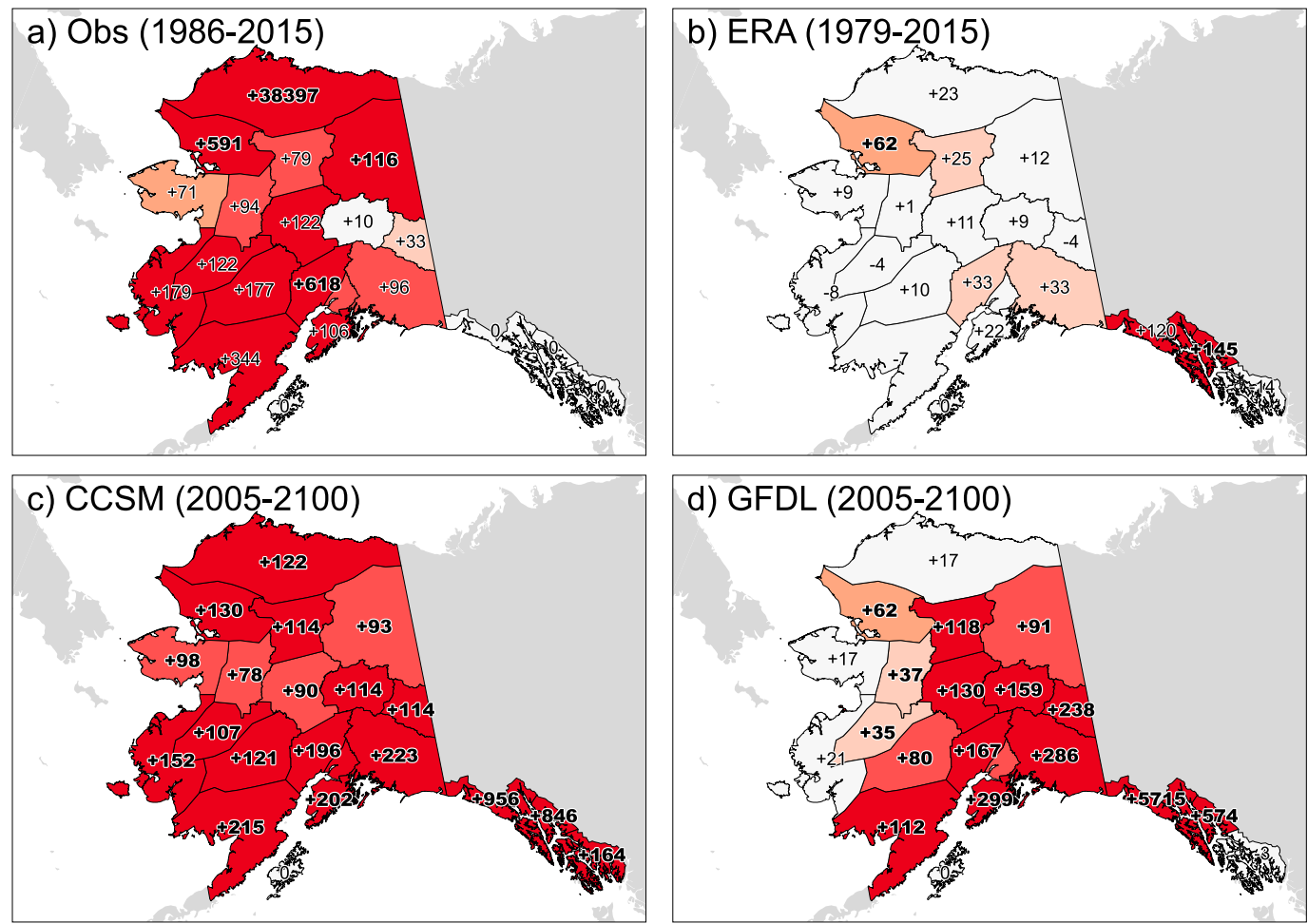

FIG. 8. Percent change of June-July lightning strike counts based on Theil-Sen trend estimators for the (a) observations over 1986-2015, and regression-estimated lightning derived from downscaled (b) ERA-Interim over 1979-2015 and (c) CCSM and (d) GFDL over 2005-2100. Darker red shading corresponds to higher positive percent change. Trends that are statistically significant at the $95 \%$ or greater level are shown in boldface.

However, these findings cannot conclusively prove that the steeper trends in the observations were due to changes in the sensor network as that would be an involved, if not unwieldy task, and is therefore beyond the scope of this study. Assessing the individual predictor variables gives additional insight into the possible variability and change of Alaska lightning activity over the historical record.

Convective precipitation was found to be a key variable based on the regression analysis in the preceding section. Over the interior PSAs, the June-July convective precipitation based on the downscaled ERAInterim reanalysis increased by $5.5 \%$ over $1979-2015$ (Fig. 9b). The 850-500-hPa temperature difference, dewpoint temperature, 2-m temperature, and 500-hPa height predictors increased by $0.2 \%, 5 \%, 6 \%$, and $0.2 \%$, respectively (Figs. 9c-f). No interior PSA predictor variable trends were statistically significant at the $95 \%$ or greater level. Direct validation of the WRF Modelderived convective precipitation variable is not possible from observations, however trends of precipitation at the climate divisions scale in the interior were relatively weak and mixed sign in June and July over 19812012 (Bieniek et al. 2014). Therefore, it is unlikely that convective precipitation has increased appreciably since 1979.

While the predictors are based on a downscaled reanalysis and not direct station observations like the lightning observations, none of the predictor values has a magnitude of change over the historical period that would suggest a doubling of lightning. It is likely that the relatively steep trends in the observed lightning dataset are spurious due to the changes in the sensor network noted earlier and that the reality of the lightning trend is better reflected by downscaled reanalysis-regression estimates of lightning activity. Consequently, our analysis suggests that lightning activity has increased over the last $30+$ years in the interior PSAs by about $17 \%$ (approximately +240 strikes per year). There are few studies that have documented trends in lightning activity in Alaska. Veraverbeke et al. (2017) show that lightning-ignited fires have increased in frequency by $4.82 \% \mathrm{yr}^{-1}$ over $1975-2015$. This value is considerably higher than the change in the amount of lightning strikes estimated by the downscaled reanalysis predictors $\left(\sim 0.4 \% \mathrm{yr}^{-1}\right)$. However, ignitions and fire spread are also dependent on the dryness of fuels and fire weather conditions (temperature, wind, relative humidity), which may 

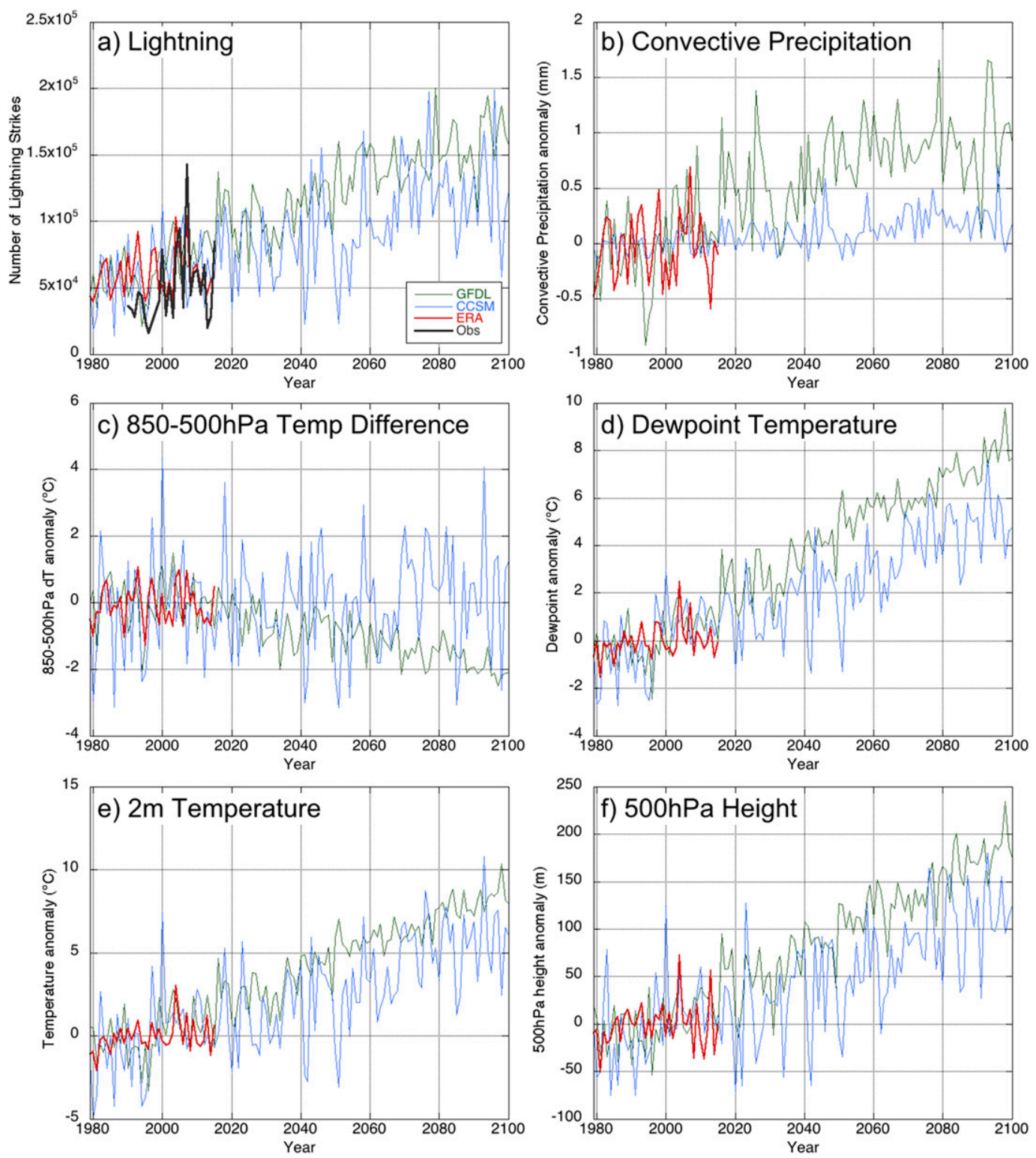

FIG. 9. June-July interior PSA (a) observed and modeled lightning strike counts, and lightning predictor variable anomalies for (b) convective precipitation, (c) 850-500-hPa temperature difference, (d) dewpoint temperature, (e) 2-m temperature, and (f) 500-hPa height. Historical lightning observations are shown in black in (a), and the downscaled estimates/variables from ERA-Interim, CCSM, and GFDL are shown in red, blue, and green, respectively, in (a)-(f). Anomalies are relative to the 1981-2010 mean.

explain why the number of fire ignitions has increased faster than the amount of lightning activity over the historical record. For example, summer temperatures have increased in interior Alaska over the past 60-70 years (Bieniek et al. 2014).

Much of the future variability of wildfire in Alaska depends on how lightning activity is anticipated to change over the next century. Figures $8 \mathrm{c}$ and $8 \mathrm{~d}$ show the percent change of June-July lightning activity estimates anticipated over 2005-2100 derived from the normalized predictor variables of the downscaled CCSM and GFDL model projections. Both models anticipate increases in lightning strike numbers throughout mainland Alaska. The CCSM projection suggested a greater percentage change over zones along the coasts than the GFDL. The overall June-July lightning strike activity for the interior PSAs is anticipated to increase by $103 \%$ ( +655 strikes per year) and $125 \%(+994$ strikes per year) for the CCSM and GFDL, respectively, over 2005-2100 (Fig. 9a). These general trends are statistically significant at the $95 \%$ or 

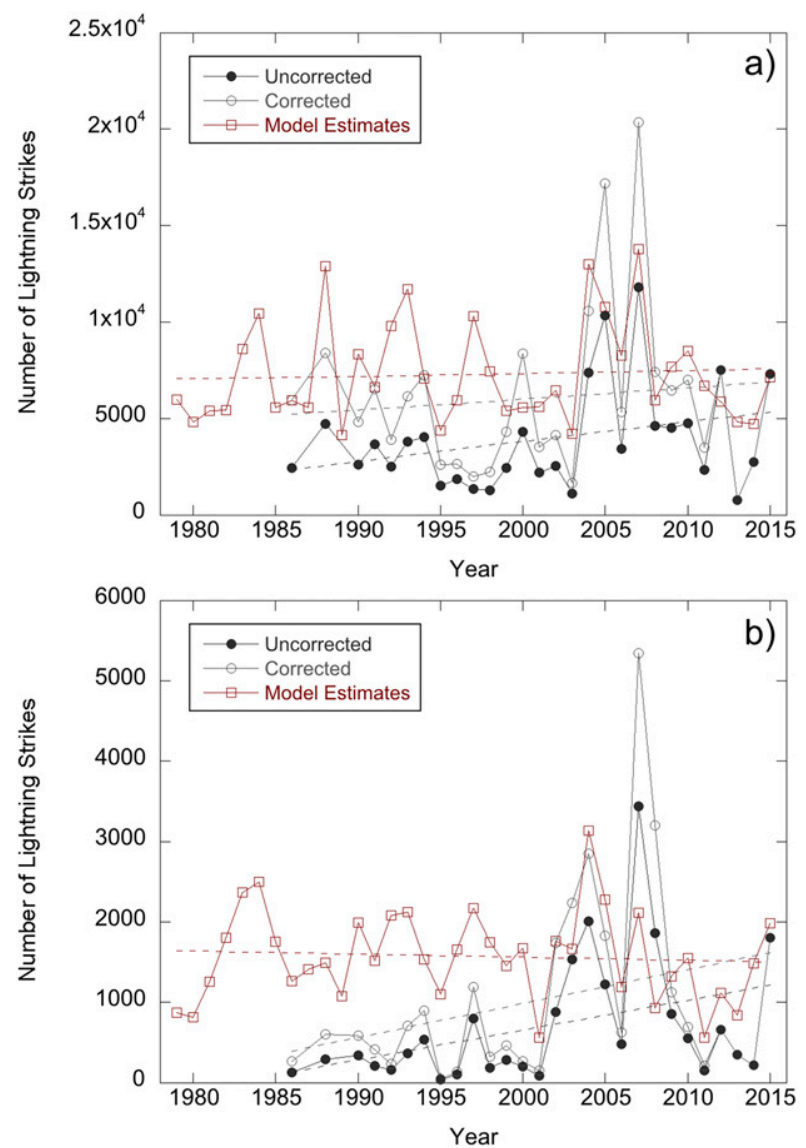

FIG. 10. June-July counts of lightning strikes from uncorrected (black lines with filled circles) and corrected (gray lines with open circles) observations, and regression model estimates (red lines with open squares) for the (a) Tanana Valley-West and (b) YukonKuskokwim Delta PSAs. The best-fit lines by linear regression are shown as dashed lines for reference, with their colors matching the corresponding variables.

greater level. The anticipated increase in June-July interior lightning activity is reflected in the projected increases seen in nearly all of the predictor variables (Figs. 9b-f). The only exception to the positive trends in the predictor variables is for the $850-500-\mathrm{hPa}$ temperature difference stability parameter from GFDL (Fig. 9c). The GFDL stability parameter shows an anticipated decline of approximately $0.02^{\circ} \mathrm{C} \mathrm{yr}^{-1}$ over $2005-2100$, indicative of increasing stability.

Lightning activity is anticipated to increase globally and regionally under climate change according to various models, scenarios, and statistical approaches (Krause et al. 2014; Price and Rind 1994; Romps et al. 2014). Veraverbeke et al. (2017) evaluated future projections of June-July lightning activity in interior Alaska among five CMIP5 models, using a regression approach as in our study, and found an average increase of $59 \%$ from the period of 1980-2004 to 2050-74. Over a similar period, our projections from CCSM and GFDL anticipate $68 \%-132 \%$ increases in our analysis, respectively, under the RCP8.5 emission scenario. Much of the difference among the models in this case is due to greater variability in the CCSM lightning estimates during 2050-74 than in GFDL (Fig. 9a). Our results are generally within the $41 \%$ error/uncertainty bounds given by Veraverbeke et al. (2017), and our projections yield even higher uncertainty. While additional downscaled emission scenarios were not available for this study, it could also be surmised that a lower emissions scenario like RCP4.5 would yield more subdued increases in lightning activity since the projected warming is not as pronounced as in RCP8.5 for Alaska and cooler surface temperatures typically result in lower rates of convection. All told, our analysis and the prior studies all highlight that lightning activity is likely to increase substantially by 2100 in interior Alaska during June-July under climate change even if there is uncertainty about the final magnitude of the change.

\section{Conclusions}

Lightning is a key driver of large wildfire in Alaska, and our analysis shows that summer lightning activity has increased over the historical record in interior Alaska, albeit with a much lower magnitude of change than the observations from ALDN would suggest. This increasing trend in historical lightning activity was estimated from modest increases in convective precipitation and other predictor variables derived from the dynamically downscaled ERA-Interim reanalysis. Although direct validation of a model-derived quantity such as convective precipitation is not possible using station observations, average summer precipitation trends over the interior better matched the modest increase in convective precipitation than the steeper increasing ALDN trends.

Downscaled future projections indicate that lightning activity may double by the end of the twenty-first century relative to current values. Such an increase in lightning strikes frequency in June-July could increase ignitions if fuel conditions remain the same as in present or worsen. If summers become generally wetter, then the impact on wildfires would be offset. Additional study is needed to incorporate changes in fire weather conditions, fuels, and lightning ignitions to fully capture how wildfire may evolve over the next century.

Acknowledgments. The authors thank Bill Beach, Jonathan Chriest, Sarah Mitchell, Akila Sampath, and the three anonymous reviewers for their comments and contributions that helped to improve this study. This work was supported by the NOAA Climate Program Office's 
Modeling, Analysis, Predictions, and Projections Program Grant NA16OAR4310142. This material is also based upon work supported by the National Science Foundation under Award OIA-1753748 and by the State of Alaska. The project described in this publication was supported by Cooperative Agreement G17AC00213 from the U.S. Geological Survey (USGS). Its contents are solely the responsibility of the authors and do not necessarily represent the views of the Alaska Climate Adaptation Science Center or the USGS. This manuscript is submitted for publication with the understanding that the U.S. government is authorized to reproduce and distribute reprints for governmental purposes.

\section{REFERENCES}

Bieniek, P. A., and Coauthors, 2012: Climate divisions for Alaska based on objective methods. J. Appl. Meteor. Climatol., 51, 1276-1289, https://doi.org/10.1175/JAMC-D11-0168.1.

_ J J. E. Walsh, R. L. Thoman, and U. S. Bhatt, 2014: Using climate divisions to analyze variations and trends in Alaska temperature and precipitation. J. Climate, 27, 2800-2818, https://doi.org/10.1175/JCLI-D-13-00342.1.

—, U. S. Bhatt, J. E. Walsh, T. S. Rupp, J. Zhang, J. R. Krieger, and R. Lader, 2016: Dynamical downscaling of ERA-Interim temperature and precipitation for Alaska. J. Appl. Meteor. Climatol., 55, 635-654, https://doi.org/10.1175/JAMC-D-150153.1.

Biswas, A., and K. Jayaweera, 1976: NOAA-3 satellite observations of thunderstorms in Alaska. Mon. Wea. Rev., 104, 292-297, https://doi.org/10.1175/1520-0493(1976)104<0292: NSOOTI $>2.0 . \mathrm{CO} ; 2$.

Budescu, D. V., 1993: Dominance analysis: A new approach to the problem of relative importance of predictors in multiple regression. Psychol. Bull., 114, 542-551, https://doi.org/10.1037/ 0033-2909.114.3.542.

Calef, M. P., A. D. McGuire, and F. S. Chapin, 2008: Human influences on wildfire in Alaska from 1988 through 2005: An analysis of the spatial patterns of human impacts. Earth Interact., 12, https://doi.org/10.1175/2007EI220.1.

Dee, D. P., and Coauthors, 2011: The ERA-Interim reanalysis: Configuration and performance of the data assimilation system. Quart. J. Roy. Meteor. Soc., 137, 553-597, https://doi.org/ 10.1002/qj.828.

Dissing, D., and D. L. Verbyla, 2003: Spatial patterns of lightning strikes in interior Alaska and their relations to elevation and vegetation. Can. J. For. Res., 33, 770-782, https://doi.org/ $10.1139 / \mathrm{x} 02-214$.

Duffy, P. A., J. E. Walsh, J. M. Graham, D. H. Mann, and T. S. Rupp, 2005: Impacts of large-scale atmospheric-ocean variability on Alaskan fire season severity. Ecol. Appl., 15, 13171330, https://doi.org/10.1890/04-0739.

Farukh, M. A., and H. Hayasaka, 2012: Active forest fire occurrences in severe lightning years in Alaska. J. Nat. Disaster Sci., 33, 71-84, https://doi.org/10.2328/jnds.33.71.

,$- \ldots$, and K. Kimura, 2011a: Characterization of lightning occurrence in Alaska using various weather indices for lightning forecasting. J. Disaster Res., 6, 343-355, https://doi.org/ 10.20965/jdr.2011.p0343.
,-- , and,$- 2011 \mathrm{~b}$ : Recent anomalous lightning occurrences in Alaska-The case of June 2005. J. Disaster Res., 6, 321-330, https://doi.org/10.20965/jdr.2011.p0321.

Fronterhouse, B. A., 2012: Alaska Lightning Detection Network (ALDN) briefing document. Bureau of Land Management Alaska Fire Service Doc., 4 pp.

Giannaros, T. M., V. Kotroni, and K. Lagouvardos, 2015: Predicting lightning activity in Greece with the Weather Research and Forecasting (WRF) model. Atmos. Res., 156, 1-13, https://doi.org/10.1016/j.atmosres.2014.12.009.

Grice, G. K., and A. L. Comiskey, 1976: Thunderstorm climatology of Alaska. NOAA (NWS Anchorage) Tech. Memo. NWS AR-14, NWS, 36 pp.

Gungle, B., and E. P. Krider, 2006: Cloud-to-ground lightning and surface rainfall in warm-season Florida thunderstorms. J. Geophys. Res., 111, D19203, https://doi.org/10.1029/ 2005JD006802.

Henry, D. M., 1978: Fire occurrence using 500mb map correlation. NOAA (NWS Anchorage) Tech. Memo. NWS AR-21, 31 pp.

Hess, J. C., C. A. Scott, G. L. Hufford, and M. D. Fleming, 2001: El Niño and its impact on fire weather conditions in Alaska. Int. J. Wildland Fire, 10 (1), 1-13, https://doi.org/10.1071/ WF01007.

Iacono, M. J., J. S. Delamere, E. J. Mlawer, M. W. Shephard, S. A. Clough, and W. D. Collins, 2008: Radiative forcing by longlived greenhouse gases: Calculations with the AER radiative transfer models. J. Geophys. Res., 113, D13103, https://doi.org/ 10.1029/2008JD009944.

Janjić, Z., 1994: The step-mountain eta coordinate model: Further developments of the convection, viscous sublayer, and turbulence closure schemes. Mon. Wea. Rev., 122, 927-945, https://doi.org/10.1175/1520-0493(1994)122<0927: TSMECM $>2.0 . \mathrm{CO} ; 2$.

Jayaratne, R., and E. Kuleshov, 2006: The relationship between lightning activity and surface wet bulb temperature and its variation with latitude in Australia. Meteor. Atmos. Phys., 91, 17-24, https://doi.org/10.1007/s00703-004-0100-0.

Kasischke, E. S., and Coauthors, 2010: Alaska's changing fire regime-Implications for the vulnerability of its boreal forests. Can. J. For. Res., 40, 1313-1324, https://doi.org/10.1139/ X10-098.

Koshak, W. J., K. L. Cummins, D. E. Buechler, B. Vant-Hull, R. J. Blakeslee, E. R. Williams, and H. S. Peterson, 2015: Variability of CONUS lightning in 2003-12 and associated impacts. J. Appl. Meteor. Climatol., 54, 15-41, https:// doi.org/10.1175/JAMC-D-14-0072.1.

Krause, A., S. Kloster, S. Wilkenskjeld, and H. Paeth, 2014: The sensitivity of global wildfires to simulated past, present, and future lightning frequency. J. Geophys. Res. Biogeosci., 119, 312-322, https://doi.org/10.1002/2013JG002502.

Krider, E., R. Noggle, A. Pifer, and D. Vance, 1980: Lightning direction-finding systems for forest fire detection. Bull. Amer. Meteor. Soc., 61, 980-986, https://doi.org/10.1175/ 1520-0477(1980)061<0980:LDFSFF>2.0.CO;2.

Lader, R., U. S. Bhatt, J. E. Walsh, T. S. Rupp, and P. A. Bieniek, 2016: Two-meter temperature and precipitation from atmospheric reanalysis evaluated for Alaska. J. Appl. Meteor. Climatol., 55, 901-922, https://doi.org/10.1175/JAMC-D-150162.1.

Lindsay, R., M. Wensnahan, A. Schweiger, and J. Zhang, 2014: Evaluation of seven different atmospheric reanalysis products in the Arctic. J. Climate, 27, 2588-2606, https://doi.org/ 10.1175/JCLI-D-13-00014.1. 
Lynch, J. A., J. L. Hollis, and F. S. Hu, 2004: Climatic and landscape controls of the boreal forest fire regime: Holocene records from Alaska. J. Ecol., 92, 477-489, https://doi.org/10.1111/ j.0022-0477.2004.00879.x.

Macias Fauria, M., and E. A. Johnson, 2006: Large-scale climatic patterns control large lightning fire occurrence in Canada and Alaska forest regions. J. Geophys. Res., 111, G04008, https:// doi.org/10.1029/2006JG000181.

Magi, B. I., 2015: Global lightning parameterization from CMIP5 climate model output. J. Atmos. Oceanic Technol., 32, 434452, https://doi.org/10.1175/JTECH-D-13-00261.1.

Markon, C., and Coauthors, 2018: Alaska. Impacts, Risks, and Adaptation in the United States: Fourth National Climate Assessment, D. R. Reidmiller et al., Eds., Vol. II. U. S. Global Change Research Program, 1185-1241, https:// doi.org/10.7930/NCA4.2018.CH26.

Melvin, A. M., J. Murray, B. Boehlert, J. A. Martinich, L. Rennels, and T. S. Rupp, 2017: Estimating wildfire response costs in Alaska's changing climate. Climatic Change, 141, 783-795, https://doi.org/10.1007/s10584-017-1923-2.

Mölders, N., and G. Kramm, 2007: Influence of wildfire induced land-cover changes on clouds and precipitation in interior Alaska-A case study. Atmos. Res., 84, 142-168, https:// doi.org/10.1016/j.atmosres.2006.06.004.

Morrison, H., G. Thompson, and V. Tatarskii, 2009: Impact of cloud microphysics on the development of trailing stratiform precipitation in a simulated squall line: Comparison of oneand two-moment schemes. Mon. Wea. Rev., 137, 991-1007, https://doi.org/10.1175/2008MWR2556.1.

Partain, J. L., and Coauthors, 2016: An assessment of the role of anthropogenic climate change in the Alaska fire season of 2015. Bull. Amer. Meteor. Soc., 97, S14-S18, https://doi.org/ 10.1175/BAMS-D-16-0149.1.

Peters, G. P., and Coauthors, 2013: The challenge to keep global warming below $2^{\circ} \mathrm{C}$. Nat. Climate Change, 3, 4-6, https:// doi.org/10.1038/nclimate1783.

Peterson, D., J. Wang, C. Ichoku, and L. A. Remer, 2010: Effects of lightning and other meteorological factors on fire activity in the North American boreal forest: Implications for fire weather forecasting. Atmos. Chem. Phys., 10, 6873-6888, https://doi.org/10.5194/acp-10-6873-2010.

Price, C., and D. Rind, 1994: Possible implications of global climate change on global lightning distributions and frequencies. J. Geophys. Res., 99, $10823-10831$, https://doi.org/10.1029/ 94JD00019.

Reap, R. M., 1991: Climatological characteristics and objective prediction of thunderstorms over Alaska. Wea. Forecasting, 6, 309-319, https://doi.org/10.1175/1520-0434(1991)006<0309: CCAOPO $>2.0 . \mathrm{CO} ; 2$.
Romps, D. M., J. T. Seeley, D. Vollaro, and J. Molinari, 2014: Projected increase in lightning strikes in the United States due to global warming. Science, 346, 851-854, https://doi.org/ 10.1126/science. 1259100 .

Shulski, M., and G. Wendler, 2007: The Climate of Alaska. University of Alaska Press, 216 pp.

Skamarock, W. C., and Coauthors, 2008: A description of the Advanced Research WRF version 3. NCAR Tech. Note NCAR/TN-475+STR, 113 pp., https://doi.org/10.5065/ D68S4MVH.

Sullivan, W. G., 1963: Low-level convergence and thunderstorms in Alaska. Mon. Wea. Rev., 91, 89-92, https://doi.org/10.1175/ 1520-0493(1963)091<0089:LCATIA > 2.3.CO;2.

Veraverbeke, S., B. M. Rogers, M. L. Goulden, R. R. Jandt, C. E. Miller, E. B. Wiggins, and J. T. Randerson, 2017: Lightning as a major driver of recent large fire years in North American boreal forests. Nat. Climate Change, 7, 529-534, https:// doi.org/10.1038/nclimate3329.

Walsh, J. E., and Coauthors, 2018: Downscaling of climate model output for Alaskan stakeholders. Environ. Modell. Software, 110, 38-51, https://doi.org/10.1016/j.envsoft.2018.03.021.

Wendler, G., J. Conner, B. Moore, M. Shulski, and M. Stuefer, 2011: Climatology of Alaskan wildfires with special emphasis on the extreme year of 2004. Theor. Appl. Climatol., 104, 459472, https://doi.org/10.1007/s00704-010-0357-9.

Wilks, D. S., 2006: Statistical Methods in the Atmospheric Sciences. 2nd ed. Academic Press, 627 pp.

Williams, E., and N. Renno, 1993: An analysis of the conditional instability of the tropical atmosphere. Mon. Wea. Rev., 121, 21-36, https://doi.org/10.1175/1520-0493(1993)121<0021: AAOTCI $>2.0 . \mathrm{CO} ; 2$.

Yair, Y., B. Lynn, C. Price, V. Kotroni, K. Lagouvardos, E. Morin, A. Mugnai, and M. C. Llasat, 2010: Predicting the potential for lightning activity in Mediterranean storms based on the Weather Research and Forecasting (WRF) model dynamic and microphysical fields. J. Geophys. Res., 115, D04205, https://doi.org/10.1029/2008JD010868.

Young, A. M., P. E. Higuera, P. A. Duffy, and F. S. Hu, 2017: Climatic thresholds shape northern high-latitude fire regimes and imply vulnerability to future climate change. Ecography, 40, 606-617, https://doi.org/10.1111/ecog.02205.

$\longrightarrow,-$, J. T. Abatzoglou, P. A. Duffy, and F. S. Hu, 2019: Consequences of climatic thresholds for projecting fire activity and ecological change. Global Ecol. Biogeogr., 28, 521-532, https://doi.org/10.1111/geb.12872.

Zhang, X., and J. Zhang, 2001: Heat and freshwater budgets and pathways in the Arctic Mediterranean in a coupled ocean/seaice model. J. Oceanogr., 57, 207-234, https://doi.org/10.1023/ A:1011147309004. 